\title{
Pine nut syndrome: a simple test for genome size of 12 pine nut-producing trees links the bitter aftertaste to nuts of $P$. armandii Zucc. ex Endl.
}

\author{
B. J. M. Zonneveld
}

Received: 18 April 2011/Accepted: 29 June 2011/Published online: 27 July 2011

(C) The Author(s) 2011. This article is published with open access at Springerlink.com

\begin{abstract}
Genome sizes of 12 pines that produce edible nuts were investigated by flow cytometry with propidium iodide. Results were compared with the genome size and taste of 11 commercial samples of pine nuts to determine which species is the cause of a lingering bitter aftertaste ("pine nut syndrome"). Each nut sample was visually separated into two to six subsets. From a single nut, the embryo and the endosperm were measured. On the basis of nuclear DNA content, pine species could be matched with their nuts. Seven out of the 11 commercial samples contained only a single pine species: P. koraiensis Sieb.\& Zucc., P. pinea L., P. armandii Zucc. ex Endl., or P. gerardiana Wall. ex Don, but the other four samples were a mix of two species. Tasting showed definitively that $P$. armandii is the origin of the bitter aftertaste. Nuclear DNA content can be measured using flow cytometry in less than $5 \mathrm{~min}$, including the calculations. This makes it easy to identify the problem-causing nuts. With hindsight, it is now also possible to identify the species of four common edible pine nuts.
\end{abstract}

Keywords Pinus species - Genome size $\cdot$ Pine nut syndrome

\section{Introduction}

Pine nuts are the edible part (kernels) of the seeds of some pine species and have been a staple food since prehistoric times. Nowadays they are an expensive gourmet product

B. J. M. Zonneveld ( $₫)$

Herbarium Section, NCB Naturalis, P.O. Box 9514,

2300 RA Leiden, The Netherlands

e-mail: Zonneveld@NHN.Leidenuniv.nl (in The Netherlands, $4 €$ for $100 \mathrm{~g}$ ) with a $\$ 100$ million market in North America alone. According to the FAO (1998), 29 pine species produce edible nuts. Of these, six are commercially important: Pinus sibirica Du Tour and P. koraiensis P. Siebold \& Zuccarini from China, P. pinea L. from southern Europe, P. gerardiana N. Wallich ex D.Don from Pakistan, and P. monophylla J. Torrey \& Fremont and $P$. edulis Engelmann from North America. Only in a few cases is the country of origin mentioned on the packets, and no mention is made of the botanical origin. All are simply sold as pine nuts. Pine nuts are an important ingredient in indigenous diets, Mediterranean dishes, and in health food. Their popularity, particularly for use in pesto and as an addition to salads, has increased.

In recent years several cases of lingering bitter or metallic aftertastes have been reported to food agencies in Denmark, UK, France, USA, and in the literature (Mostin 2001; Picard and Landis 2010; Munk 2010). More and more reports have also begun to appear on the internet about "pine nut syndrome" (PNS), also called pine mouth, dysgeusia, metallogeusia, or cacogeusia. The French food safety authority AFSSA (2009) has reports of 800 cases. Anecdotal comments on the internet suggest that PNS is correlated with eating pine nuts from China. Investigations have not revealed any pesticide residues, toxins, or high concentrations of heavy metals (Mostin 2001).

A recent report based on oil profiles of the nuts indicated $P$. armandii Zuccarini ex Endlicher and also possibly P. massoniana A. Lambert as the cause (Destaillats et al. 2010). Later Destaillats et al. (2010) "confirmed" their earlier conclusion based on an analysis of 16 samples submitted as having caused dysgeusia (but whose bitterness was not tested by Destaillats et al.). AFFSA (2009) indicates $P$. koraiensis P. Siebold ex Zuccarini as the origin of the syndrome, but it also states that further investigations 
should be done with $P$. armandii. Recently the Directorate General for Competition, Consumption and Fraud Control (DGCCRF) suggested that a botanical species of pine is involved. However, it was not immediately identifiable. Therefore, it was recommended that only species listed by the FAO (1998) can be consumed in France. Thus at present none of the reports are conclusive. It has only been suggested that there seems to be a link between PNS and recently imported Chinese pine nuts.

In this article, the botanical origin of pine nuts was investigated by measuring the nuclear DNA content by flow cytometry, a fast and cheap method. It has previously been successfully used to measure the genome sizes of all species for the genera Hosta Tratt., Helleborus L., Tulipa L. Narcissus, Eucomis, Hepatica, and others (Zonneveld and van Iren 2001; Zonneveld 2001, 2008, 2009, 2010a, 2010b).

Nuclear DNA content and taste were used to link the commercially available pine nuts to specific species of pine. This shows definitively that $P$. armandii, sold separately and in mixes, caused the bitter aftertaste.

\section{Materials and methods}

\section{Plant material}

Material of pine nut-producing trees was obtained mainly from the collections of Arboretum Trompenburg (Rotterdam, The Netherlands), Pinetum Blijdenstein (Hilversum, The Netherlands), and Pinetum Anthoine (Jamioulx, Belgium). Care was taken to ensure correct identification of all tree material.

The nuts were obtained from Noes Voogd, Basel, Switzerland (sample A), from Boulogne-sur-mer, France (samples B and C), and from local shops (Leiden, The Netherlands) (samples D-L).

Flow cytometric measurement of 2C DNA value

For the isolation of nuclei from the pine branches, a bud or the tip of a young shoot was chopped together with a piece of Agave americana L. 'Aureomarginata' as an internal standard (see below). Whole nuts were measured one by one or the embryo alone was used after it was removed from the endosperm. The chopping was done with a new razor blade in a petri dish in $0.25 \mathrm{ml}$ nuclei-isolation buffer to which $0.25 \mathrm{mg} \mathrm{RNase} / \mathrm{ml}$ was added (Zonneveld and van Iren 2001). After adding $1.75 \mathrm{ml}$ propidium iodide solution (50 $\mathrm{mg} \mathrm{PI} / 1$ in isolation buffer), the suspension with nuclei was filtered through a $30 \mu \mathrm{m}$ nylon filter. The fluorescence of the nuclei was measured $30 \mathrm{~min}$ and $1 \mathrm{~h}$ after addition of propidium iodide, using a Partec CA-II flow cytometer. The optical path contained an HBO mercury lamp, filters KG1 and BG12, dichroic mirror TK500, filter OG570, and a Leitz $50 \times 1$ water immersion objective.

Data were analyzed by means of DPAC software (Partec). The 2C DNA content of the sample was calculated as the sample peak mean, divided by the Agave peak mean, and multiplied by the amount of DNA of the Agave standard. Most samples were measured at least 10 times, each time with at least 5,000 nuclei. Most histograms revealed a coefficient of variation of around 5\%. The standard deviation was calculated for the DNA content of each species, using all relevant measurements.

Internal standard and absolute DNA content values

When measuring nuclear DNA content by means of flow cytometry, it is necessary to chop tissue from the plant of interest together with an internal standard: this standard must be as close as possible to the plants of interest. In this way, variation in signal intensities due to staining kinetics, to light absorption and quenching by sample components, as well as to the instrument and other variables is reduced to a minimum. Agave americana was chosen as internal standard for both the nuts and the branches. Agave americana is available year-round, does not mind several weeks without water and, being a large plant, a single specimen can serve a lifetime, thereby further reducing variation in readings. It also has a low background in propidium iodide measurements and shows a single $G_{0}$ peak, almost lacking $G_{2}$ arrest.

Fresh male human leucocytes $(2 \mathrm{C}=7.0 \mathrm{pg} ; 1$ picogram $=10^{-12}$ gram $=0.978 \times 10^{9}$ base pairs) $($ Dolezel et al. 2003) were chosen as primary standard (Tiersch et al. 1989). This yields $2 \mathrm{C}=15.9 \mathrm{pg}$ for nuclei of Agave americana $\mathrm{L}$.

\section{Results}

Nuclear DNA content of pine nuts

Eleven samples of pine nuts were obtained from local shops (Leiden, The Netherlands) and from Basel (Switzerland) and Boulogne-sur-mer (France). Each sample was divided into two to six subsamples based on size, shape, and color of the nuts. In total nearly 400 measurements were done. In the end several subsamples from a sample found to contain a single species were combined. On the packages for samples $\mathrm{A}$ and $\mathrm{B}$, it was mentioned that the nuts were collected in Turkey and Portugal, respectively, and sample $\mathrm{C}$ stated that it came from Pakistan. First, whole nuts were measured. Both endosperm and embryo did give a separate peak as the endosperm of gymnosperms 
is haploid. For comparison the amounts of nuclear DNA (2C value) for the endosperm are doubled. Later, the embryo from a single nut was measured after removal of the endosperm. Three values are mentioned: those for whole nuts with a figure both for the endosperm and the embryo and a column for the embryo alone. Four different genome sizes could easily be recognized in the sampled nuts (Table 1). These had nuclear DNA contents of 56.8, 62.0, 65.2, and $71.9 \mathrm{pg}$.

Sample A from France and sample B from Switzerland were found to have a nuclear DNA content of $56.8 \mathrm{pg}$. These did not contain another species nor was this value found in any of the other samples. The same is true for the sample from France (C) with 71.9 pg. This sample also contained only a single species not found in any of the other samples. They were from Pakistan and could easily be recognized by their large $(>20 \mathrm{~mm})$ cigar-shaped nuts. A sample with roasted nuts bought later in Leiden also from Pakistan was not measured but looked identical.

The value of $62.0 \mathrm{pg}$ was found in two pure samples (D, E) from Leiden shops and also in four mixed samples (H-L). These mixed samples also contained smaller, black -tipped nuts with a nuclear DNA content of $65.2 \mathrm{pg}$. This value was also found pure in two other samples, F and G.

\section{Nuclear DNA content of pine trees}

There are about 97-110 pine species (Eckenwalder 2009; Farjon 2011). Fresh branches of 12 pine nut-providing species were obtained from several gardens (See "Materials and methods").
The European $P$. pinea had a nuclear DNA content of $56.8 \mathrm{pg}$. This amount of nuclear DNA was found for all nuts of samples A and B (Table 2).

Three nut-producing pines from North America were also measured, although it is unlikely that their nuts are found in Europe as they are mainly consumed locally. They are $P$. edulis $(59.2 \mathrm{pg}), P$. remota (E. Little) D. Bailey \& F. Hawksworth (59.7 pg), and P. monophylla J. Torrey \& Fremont with $63.1 \mathrm{pg}$. No nuts could be obtained from these latter three species. Last year (2010) the crop in North America largely failed, so up to $80 \%$ of pine nuts sold were imported from China. The PNS problem was never reported in North America before the massive Chinese imports, so the Native American nuts are likely not involved in PNS.

Although they are also pine nut producers, pine nuts with the nuclear DNA content of $P$. wallichiana A. B. Jackson $(59.6 \mathrm{pg}$ ) and the three closely related species $P$. sibirica Du Tour (59.8 pg), P. cembra L. (60.1 pg), and P. pumila L. P. Pallas \& E. Regel (59.7 pg) were not found in our nut samples. Pinus massoniana was also indicated as a possible cause of the syndrome by Destaillats et al. (2010). However, its nuclear DNA content of only $51.6 \mathrm{pg}$ was not found among our nut samples. Pinus roxburghii C. Sargent from India is only used locally (FAO 1998), and with $61.7 \mathrm{pg}$ is clearly different from $P$. gerardiana from the same area with 71.9 pg. Pinus koraiensis $(62.0 \mathrm{pg})$ and $P$. gerardiana (71.9 pg) are the most widely harvested nuts in Asia.

Pinus koraiensis has $62.0 \mathrm{pg}$ and was found in samples $\mathrm{D}$ and E. Moreover, about half the nuts in the four mixed samples had this value. The other half of the mix could be
Table 1 Pine nut samples and their mean nuclear DNA contents in picograms, standard deviations, number of measurements, and conclusion

\begin{tabular}{|c|c|c|c|c|c|c|}
\hline Sample & $\begin{array}{l}\text { Whole nuts: } \\
\text { endosp. } \times 2 \\
(\text { pg } 2 \mathrm{C} \text { DNA) }\end{array}$ & $\begin{array}{l}\text { Whole nuts: } \\
\text { embryo } \\
\text { (pg 2C DNA) }\end{array}$ & $\begin{array}{l}\text { Embryo alone } \\
\text { (pg 2C DNA) }\end{array}$ & $\begin{array}{l}\text { Standard } \\
\text { deviation }\end{array}$ & $\begin{array}{l}\text { Measurements } \\
(n)\end{array}$ & Conclusion \\
\hline A & 57.2 & 56.9 & 55.3 & 2.3 & 11 & P. pinea \\
\hline B & 57.5 & 56.2 & 56.4 & 1.7 & 10 & $P$. pinea \\
\hline $\mathrm{C}$ & 78.7 & 74.5 & 75.6 & 3.1 & 11 & P. gerardiana \\
\hline $\mathrm{D}$ & 62.2 & 62.1 & 60.7 & 1.1 & 24 & P. koraiensis \\
\hline E & 62.2 & 62.0 & 61.3 & 1.8 & 23 & P. koraiensis \\
\hline $\mathrm{H} 1$ & 61.6 & 61.2 & 61.2 & 1.5 & 37 & P. koraiensis \\
\hline $\mathrm{J} 1$ & 61.8 & 61.9 & 61.2 & 0.3 & 16 & P. koraiensis \\
\hline K1 & 62.6 & 62.0 & 59.8 & 0.8 & 20 & P. koraiensis \\
\hline L1 & 63.7 & 63.4 & 62.0 & 1.7 & 49 & P. koraiensis \\
\hline $\mathrm{F}$ & 64.7 & 64.8 & 65.8 & 0.9 & 31 & $P$. armandii \\
\hline G & 66.4 & 65.8 & 65.1 & 1.3 & 16 & $P$. armandii \\
\hline $\mathrm{H} 2$ & 64.7 & 64.5 & 64.3 & 1.1 & 34 & $P$. armandii \\
\hline $\mathrm{J} 2$ & 63.5 & 64.1 & 65.2 & 0.7 & 13 & P. armandii \\
\hline $\mathrm{K} 2$ & 67.3 & 69.7 & 68.9 & 1.4 & 10 & P. armandii \\
\hline L2 & 64.6 & 64.1 & 63.6 & 1.9 & 17 & P. armandii \\
\hline
\end{tabular}


Table 2 Pine branches and their mean nuclear DNA (2C) contents in picograms, standard deviations, number of measurements, origins, and sources

\begin{tabular}{|c|c|c|c|c|c|}
\hline & $\begin{array}{l}\text { DNA }(2 \mathrm{C}) \text { per } \\
\text { nucleus }(\mathrm{pg})\end{array}$ & $\begin{array}{l}\text { Standard } \\
\text { deviation }\end{array}$ & $\begin{array}{l}\text { Measurements } \\
(n)\end{array}$ & Origin & Source \\
\hline P. massoniana A. Lambert & 51.6 & 1.2 & 12 & Southern China & Pin. Anthoine \\
\hline$P$. pinea $\mathrm{L}$. & 56.8 & 0.8 & 4 & Southern Europe & Arb. Trompenburg \\
\hline P. edulis Engelmann & 59.2 & 1.5 & 14 & Southwestern USA & Arb. Trompenburg \\
\hline P. wallichiana A.B. Jackson & 59.6 & 0.7 & 6 & Himalayas & Arb. Trompenburg \\
\hline P. remota (Elittle) D. Bailey\& F. Hawksworth & 59.7 & 1.0 & 8 & Texas & Arb. Trompenburg \\
\hline P. pumila L.P. Pallas \& E. Regel & 59.7 & 0.7 & 10 & Japan & Pin. Anthoine \\
\hline P. sibirica Du Tour & 59.8 & 0.9 & 12 & Northern China & Pin. Anthoine \\
\hline P. cembra L. & 60.1 & 1.2 & 12 & Europe & Arb. Trompenburg \\
\hline P. koraiensis P. Siebold \& Zuccarini & 62.0 & 0.5 & 12 & China & Arb. Trompenburg \\
\hline P. monophylla J. Torrey \& Fremont & 63.1 & 1.0 & 6 & North America & Arb. Trompenburg \\
\hline$P$. armandii Zuccarini ex Endlicher & 65.2 & 0.7 & 8 & China & Arb. Trompenburg \\
\hline P. gerardiana N. Wallich ex D. Don & 71.9 & 0.9 & 12 & India/Pakistan & Arb. Trompenburg \\
\hline
\end{tabular}

equated with $P$. armandii with $65.2 \mathrm{pg}$. Nuts of samples $\mathrm{F}$ and $\mathrm{G}$ turned out to be all from this latter species. This result is remarkable as $P$. armandii is not mentioned among the 29 edible nut producers listed in the edible pine nut compendium of the FAO (1998). Six more samples from local shops were visually inspected only. Three contained only $P$. koraiensis, one was $P$. armandii only, and two were again a mix of $P$. koraiensis with $P$. armandii.

Testing for the bitter aftertaste

The 11 samples divided in two to six subsamples were tested for the bitter taste by two sensitive persons. This is quite time consuming as the bitter taste only develops after 1-2 days, and once a bitter nut is eaten, the tester must wait for the bitter taste to disappear before the next sample can be tested. After some testing, it was found that it was necessary to consume at least six nuts in each trial as the bitter taste did not appear in our case when fewer nuts were consumed. The nuts of $P$. armandii do not actually taste different. However, 1-2 days after consumption, the syndrome develops. The intake of almost every food or beverage triggers a metallic or bitter taste. This lasts for a few to 14 days and disappears without any treatment. Neither roasting nor processing as in pesto seems to make a difference. Not everyone is sensitive to it. The severity seems to depend both on the sensitivity of the person and on the amount consumed.

Only the samples containing $P$. armandii gave the bitter aftertaste. Pinus bungeana Franchet is also from China and also has DNA content of about $65 \mathrm{pg}$. It could be excluded as it is very rare in nature (Eckenwalder 2009), its seeds seem too small to contain the kernels found in the samples, and its cones are half the size of those of $P$. armandii. The latter was checked by inspecting the carpologia in the Leiden herbarium.

\section{Discussion}

Nestlé researchers (Destaillats et al. 2010) analyzed the oil composition of ten commercial pine nut samples from France and Switzerland by gas-liquid chromatography (Wolff et al. 2001). Only one sample was a mixture of $P$. armandii and $P$. koraiensis. This sample was one in which a taste disturbance was experienced by a consumer. Unfortunately the other samples were not tested for bitterness. Ten grams of nuts (equal to about 75 nuts) from one sample were extracted together. So it cannot be excluded that other mixtures escaped notice. The authors also stated that taste disturbance owing to the products of oxidation was not likely as a bitter taste that lasts for more than one week is usually not experienced with lipid oxidation products. Several of our samples contained dried-up nuts from $P$. koraiensis, likely one year old. These did not give a bitter taste. This seems to corroborate the conclusion that rancidness in not the cause. In a later article of Destaillats et al. (2011), their conclusion was again that $P$. armandii, with a diagnostic index (DI) of 2.92, was the cause. It is peculiar, however, how they reached this conclusion, as the average of the diagnostic index $(\mathrm{DI}=3.00)$ of the 16 (sub)samples pointed to $P$. siberica $(\mathrm{DI}=3.02$ ). They resolved this by dividing the 16 (sub)samples into one group of 11 that represented $P$. armandii $(\mathrm{DI}=2.92)$ and considering the variation in the other five samples 
(average DI $=3.16$ ) as being due to natural variation. This seems to indicate a low reliability of the method used.

Further observations are that, in most samples but not in those of $P$. armandii or $P$. pinea, the roots of the embryo were dried up. This is probably caused by heating the cones to extract the nuts. This is not necessary in $P$. armandii or $P$. pinea as the scales of their ripe cones open wide, releasing the seeds. Moreover, most of the embryos had greenish-yellow cotyledons, except those of $P$. pinea, which were white. Some of the nuts of $P$. koraiensis have black points, and these should not be confused with smaller $P$. armandii nuts, which nearly always have a black point.

Parrot fanciers give their larger birds small and large "cedar" seeds, which are actually pine seeds. Measurements indicate that the large seeds are $P$. koraiensis and the smaller ones $P$. armandii. One wonders if the birds experience the same bitter sensation.

It has been reported by some that the bitter aftertaste can be (temporarily) relieved by eating foods such as lemons, grapes, ginger, or Chinese food. In China they experience the bitter taste too, but the nuts are sold as sugar-covered candies (Babyccinokids 2009). Maybe we have here a case of cultural misunderstanding. Perhaps the $P$. armandii nuts were not intended to be mixed with $P$. koraiensis but to be used after covering them with sugar.

A possible explanation for the observed symptoms is given by Möller (2010). He very elegantly deduces the possible pathway for the bitter taste. Pinolenic acic in pine nuts induces the production of the hormone cholecystokinin (Pasman et al. 2008) in the upper intestine. It stimulates the gall bladder to release bile in the duodenum and induces the liver to produce more bile. The authors found an eightfold difference in pinolenic acid between two pine species. Further there are bitter taste receptors present in the gastrointestinal tract (Wu et al. 2002). Excess bile can cause the metallic or bitter aftertaste as there is a crosswiring of the brain's neurological bitter sensation of the tongue and the gastrointestinal tract. The products of digestion in the small intestine reach the liver via the portal vein. The liver excretes any waste products via the gall bladder higher up in the duodenum. So substances derived from the nuts and excreted via the liver by the gall bladder can be taken up again lower down via the portal vein. This bile reflux extends the residence time in the gut and can explain why it sometimes takes more than 1 week for the bitter taste to disappear and why it takes 1 or 2 days for the symptoms to appear. It might also explain the occasionally reported cases of diarrhea, nausea, and abdominal cramping. A woman even reported that her baby refused to nurse for 1 week. No further health effects have been reported, but it cannot be excluded that liver patients might have some adverse effects.

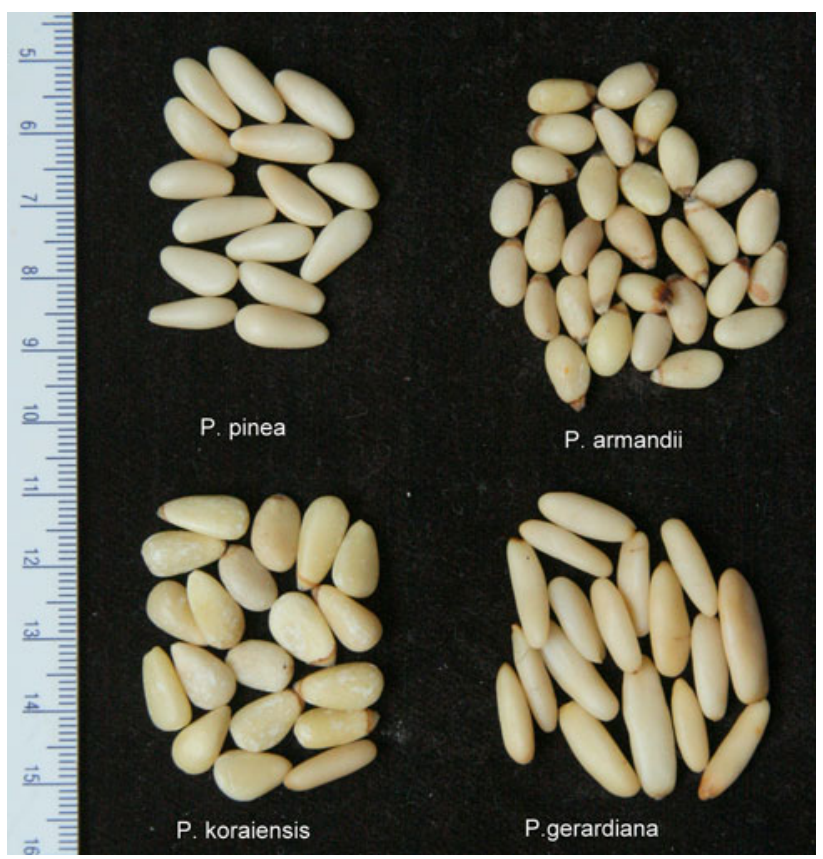

Fig. 1 Examples of the four pine nut varieties found in 11 samples from France, Switzerland, and The Netherlands

\section{Conclusions}

1. The Eurasian P. sibirica, P. massoniana, P. cembra, $P$. wallichiana, $P$ roxburghii, and the North American $P$. remota, $P$. edulis, and $P$. monophylla nuts were likely not present in the investigated 11 samples.

2. P. pinea, $P$. gerardiana, and $P$. koraiensis were present but did not trigger a bitter aftertaste.

3. The bitter taste experienced by many people is caused by $P$. armandii from China. Compared to the other three mentioned species, the grayish-beige nuts are smaller, are egg shaped, and have a black tip (Fig. 1).

4. Early recognition of the symptoms will reassure patients at an early stage and might prevent needless and expensive investigations.

5. The analytical procedure presented here is a fast, cheap, and easy way to determine the composition of pine nut samples.

Open Access This article is distributed under the terms of the Creative Commons Attribution Noncommercial License which permits any noncommercial use, distribution, and reproduction in any medium, provided the original author(s) and source are credited.

\section{References}

AFSSA (2009) Information regarding reports of bitter taste following consumption of pine nuts. Request no 2009-SA-0166:1-2. 
Agence Française de Sécurité Sanitaire des Aliments, MaisonsAlfort

Babyccinokids (2009) The bitter after-taste of Chinese pine nuts. http://babyccinokids.com/2009/02/03/the-bitter-after-taste-ofchinese-pine-nuts/

Destaillats F, Cruz-Hernandez C, Giuffrida F, Dionisi F (2010) Identification of the botanical origin of pine nuts found in food products by gas-liquid chromatography analysis of fatty acid profile. J Agric Food Chem 58(4):2082-2087

Destaillats F, Cruz-Hernandez C, Giuffrida F, Dionisi F, Verstegen G (2011) Identification of the botanical origin of commercial pine nuts responsible for dysgeusia by gas-liquid chromatography analysis of fatty acid profile. $\mathrm{J}$ Toxic (in press)

Dolezel J, Bartos J, Voglmayer H, Greilhuber J (2003) Nuclear DNA content and genome size of trout and human. Cytometry 51a: $127-128$

Eckenwalder JE (2009) Conifers of the world: the complete reference. Timber, Portland

FAO (1998) Seeds, fruits, and cones. In: Non-wood forest products from Conifers. Food and Agriculture Organization of the United Nations, Rome

Farjon A (2011) A handbook of the world conifers, vol 2. Brill, Leiden

Möller G (2010) The curious case of the epicurean nut. Food Techn Mag 64(5):1-6

Mostin M (2001) Taste disturbances after pine nut ingestion. Presented at the XXXVIII congress of the Society for Clinical Toxicology (abstract). J Emerg Med 8(1):76

Munk MD (2010) "Pine mouth" syndrome: cacogeusia following ingestion of pine nuts (genus: Pinus). An emerging problem? J Med Toxicol 6:158-159

Pasman WJ, Heimerikx J, Rubingh CM, van den Berg R, O'Shea M, Gambell L, Hendriks HFJ, Einerhand AWC, Scott C, Keizer HG,
Mennen LI (2008) The effect of Korean pine nut oil on in vitro CCK release, on appetite sensations and on gut hormones in post-menopausal overweight women. Lipids Health Dis 7(10). doi:101186/1476-511X-7-10

Picard F, Landis BN (2010) Pine nut induced dysgeusia: an emerging problem. Am J Med. doi:101016/jamjmed201003033

Tiersch TR, Chandle RW, Wachtel SSM, Ellias S (1989) Reference standards for flow cytometry and application in comparative studies of nuclear DNA content. Cytometry 10:706-710

Wolff RL, Lavialle O, Pedrono F, Pasquier E, Deluc LG, Marpeau AM, Aitzetmuller K (2001) Fatty acid composition of Pinaceae as taxonomic markers. Lipids 36:439-451

Wu SV, Rozengurt N, Yang M, Young SH, Sinnett-Smith J, Rozengurt E (2002) Expression of bitter taste receptors of the T2R family in the gastrointestinal tract and enteroendocrine STC-1 cells. Proc Nat Acad Sci USA 99(4):2392-2397

Zonneveld BJM (2001) Nuclear DNA contents of all species of Helleborus discriminate between species and sectional divisions. Plant Syst Evol 229:125-130

Zonneveld BJM (2008) The systematic value of nuclear DNA content for all species of Narcissus L (Amaryllidaceae). Plant Syst Evol 275:109-132

Zonneveld BJM (2009) The systematic value of nuclear genome size for all species of Tulipa L. (Liliaceae). Plant Syst Evol 281:217245

Zonneveld BJM (2010) New record holders for maximum genome size in eudicots and monocots. J Bot. doi:101155/2010/527357

Zonneveld BJM (2010) Genome sizes in Hepatica Mill (Ranunculaceae) show a loss of DNA not a gain, in polyploidy. J Bot. doi: 101155/2010/758260

Zonneveld BJM, Van Iren F (2001) Genome size and pollen viability as taxonomic criteria: application to the genus Hosta. Plant Biol $3: 176-185$ 